\title{
Non-traumatic tension gastrothorax in a young lady
}

\author{
Mahmut Tokur, M.D., ${ }^{1}$ Ş. Mustafa Demiröz, M.D., ${ }^{1}$ Muhammet Sayan, M.D. ${ }^{2}$ \\ 1'Department of Thoracic Surgery, Kahramanmaras Sutcu Imam University Faculty of Medicine, Kahramanmaras \\ ${ }^{2}$ Department of Thoracic Surgery, Aksaray State Hospital, Aksaray
}

\begin{abstract}
Tension gastrothorax is a very rare but potentially fatal clinical condition in which the stomach that herniates through a diaphragmatic defect into the thorax is massively distended by trapped air. It leads to severe symptoms due to the compression of the lung and mediastinum. A 27-year-old female, who had no prior trauma history, applied to the emergency service with the complaint of respiratory disorder, and was consulted by the department of thoracic surgery. Thorax CT revealed presence of gastrothorax in the left hemithorax. Thus, the patient went into cardiopulmonary arrest and was resuscitated. Emergency thoracotomy was performed, abdominal organs were reduced and diaphragmatic defect was repaired. She was discharged on the fifth postoperative day without any complications.
\end{abstract}

Key words: Diaphragmatic rupture; emergency thoracotomy; tension gastrothorax.

\section{INTRODUCTION}

Tension gastrothorax is a very rare and life-threatening condition which radiologically mimics tension pneumothorax. [1] Visceral organs that herniate into the thorax through a diaphragmatic defect lead to this clinical condition. This diaphragmatic defect may be congenital or secondary to blunt or penetrating thoracic traumas, or it may also be iatrogenic. [2] Surgery is the choice of treatment; early gastric decompression applied in the emergency setting may save life. ${ }^{[3]}$

\section{CASE REPORT}

A 27-year-old female was admitted to the emergency service with the complaints of nausea, shortness of breath and abdominal pain existing for five days. Physical examination revealed hypotension, tachycardia, and loss of respiratory sounds on the left hemithorax. On chest X-ray, there was no lung parenchyma on the left side and mediastinal shift to the right side was present (Fig. I). Thorax CT revealed to-

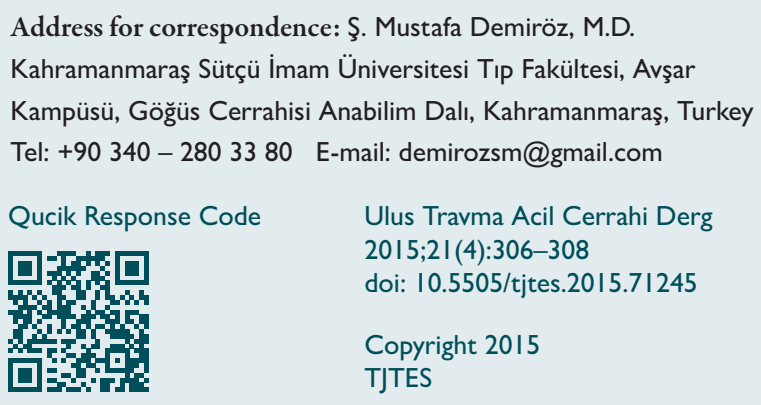

tal gastric herniation through a left side diaphragmatic defect (Fig. 2). Thus, cardiopulmonary arrest developed on the CT table, the patient was resuscitated, and an emergency thoracotomy was performed. Herniated organs were reduced and diaphragmatic defect was primarily repaired. Postoperative chest $\mathrm{x}$ ray showed expanded left lung and improved mediastinal shift (Fig. 3). Postoperative course was uneventful. The patient was discharged on the fifth postoperative day.

\section{DISCUSSION}

Tension gastrothorax is a clinical condition which defines the herniation of some abdominal organs, especially the stomach, into the thorax due to several disorders, mimicking tension pneumothorax by causing contralateral mediastinal shift and hemodynamic instability. ${ }^{[1]}$ This entity is thought to be a late complication of unrecognized traumatic diaphragmatic hernia. Therefore, determining the real incidence is difficult.. ${ }^{[4]}$ Tension gastrothorax develops through congenital diaphragmatic defects, iatrogenic defects (tube thoracostomy, esophageal interventions, diaphragmatic plication, and etc.) or traumatic diaphragmatic ruptures. In several reports, traumatic diaphragmatic defects have been notified to be seen in 3-5\% and $10-$ $15 \%$ respectively after blunt and penetrating traumas, mostly on the left ( 3 times as much as the right side). However, traumatic gastrothorax is very rare. ${ }^{[2]}$ In the index case, there was no history of trauma or former surgical intervention, and therefore, herniation through a congenital defect was thought in the etiology. In the diagnosis of such a rare entity, clinical suspicion is very important because there are no pathognomonic findings of diaphragmatic rupture and gastrothorax. ${ }^{[4]}$ 
Clinically, it may mimic tension pneumothorax. Findings such dyspnea, hypotension (secondary to mediastinal vascular compression), tachycardia, intestinal sounds on the left hemithorax may be seen. ${ }^{[1]}$ Late cases may admit by progressive left side pain, shortness of breath, and vomiting. In addition, cardiopulmonary arrest may occur due to mediastinal compression and acute venous return failure. ${ }^{[4]} \mathrm{Kao} Y$ and colleagues have reported a patient with tension gastrothorax as a late complication of a prior blunt thoracic trauma, who had abdominal distension, epigastric pain and persistent hiccup at the time of admission. ${ }^{[2]}$ In our case, symptoms on admission were shortness of breath, epigastric pain and nausea. These symptoms and our findings (hypotension, tachycardia and loss of respiratory sounds on left hemithorax) were in accordance with the literature.

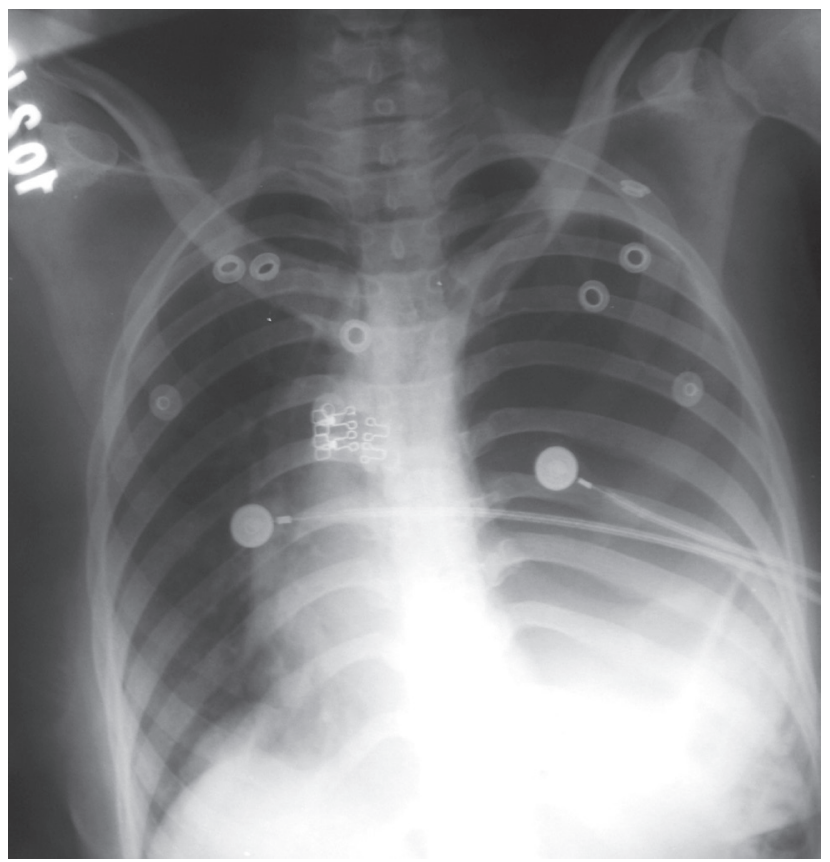

Figure 1. Chest X-ray upon hospital admission, showing findings of tension pneumothorax.

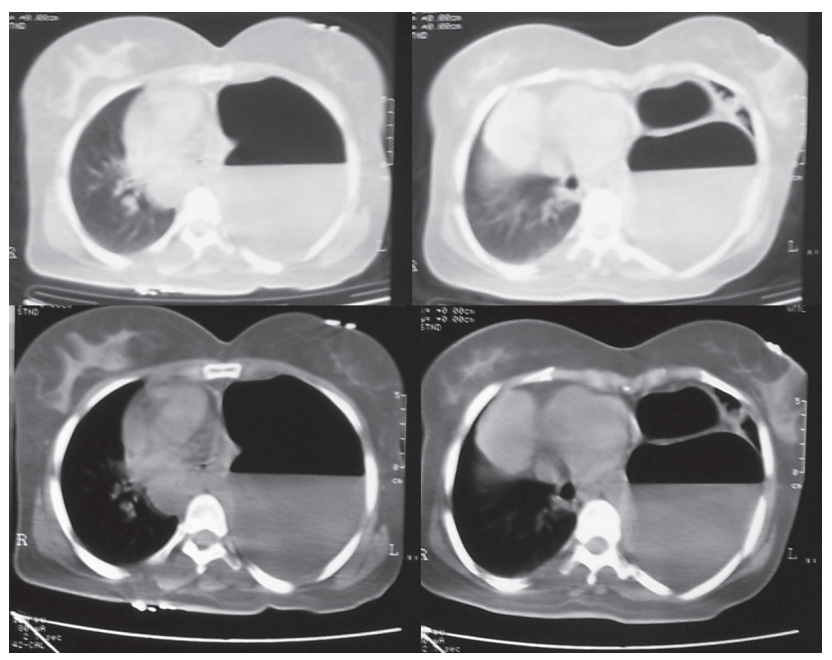

Figure 2. Thorax CT scan reveal findings of gastrothorax.

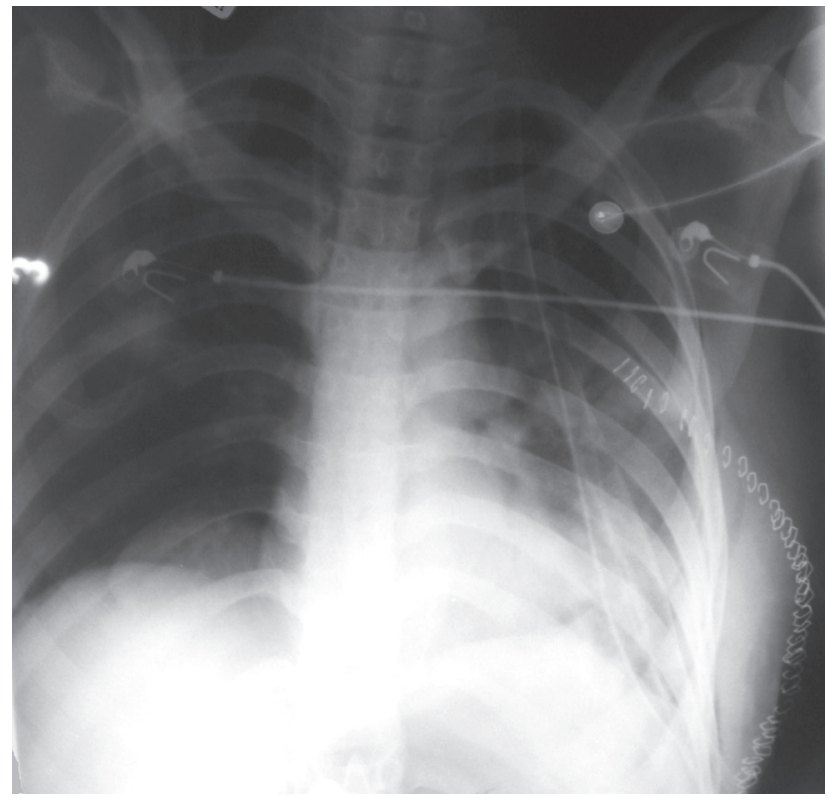

Figure 3. Postoperative chest X-ray.

In another case report of gastrothorax secondary to blunt trauma by McCann and colleagues, there were gas bubbles, diaphragm contour abnormality, diaphragmatic elevation and compression atelectasis of the left lower lobe found on chest $X$-ray. ${ }^{[I]}$ In another case report, there were only findings of tension pneumothorax on chest X-ray. ${ }^{[5]}$ Rathinam and colleagues have reported fluid-gas level on the left hemithorax in a pediatric patient with tension gastrothorax. ${ }^{[4]}$ In index case, only findings of tension pneumothorax were seen on chest X-ray.

The improvement in symptoms by nasogastric decompression and sighting of nasogastric catheter in the thorax on chest $X$-ray may bring tension gastrothorax into mind. ${ }^{[3]}$ Thorax CT findings include the presence of diaphragmatic rupture or defect, herniated abdominal organs into the thorax, contralateral mediastinal shift, compression atelectasis on the left lung, and concomitant thoracic or abdominal organ injuries. ${ }^{[1,5]}$

In treatment, emergency nasogastric catheter insertion may be lifesaving besides general medical preventions. ${ }^{[1]}$ Some authors suggest gastric decompression by transthoracic needle aspiration to gain time for surgery and obtain clinical stability when nasogastric decompression fails..$^{[3,5]}$

The optimal choice of treatment for traumatic diaphragmatic hernias is surgery. Correct diagnosis and urgent surgical treatment decrease morbidity and mortality rates. ${ }^{[2,6]}$ For surgical treatment, thoracotomy, laparotomy or both may be performed. Abdominal organ reduction and primary diaphragmatic repair are performed. Rapid expansion of the left lung may lead re-expansion pulmonary edema. ${ }^{[4,5]}$

\section{Conclusion}

Tension gastrothorax is a very rare clinical entity. An accurate 
differential diagnosis with tension pneumothorax is required. Treatment is based on general medical preventions and nasogastric decompression followed by surgical therapy. As in our case, it may occur as a late complication of congenital diaphragmatic defect without any history of prior trauma or operation.

Conflict of interest: None declared.

\section{REFERENCES}

1. McCann B, O'Gara A. Tension viscerothorax: an important differential for tension pneumothorax. Emerg Med J 2005;22:220-1. CrossRef
2. Kao Y, Lee WJ, Lin HJ. Tension gastrothorax: a life-threatening cause of acute abdominal pain. CMAJ 2009;180:983. CrossRef

3. Slater RG. Tension gastrothorax complicating acute traumatic diaphragmatic rupture. J Emerg Med 1992;10:25-30. CrossRef

4. Rathinam S, Margabanthu G, Jothivel G, Bavanisanker T. Tension gastrothorax causing cardiac arrest in a child. Interact Cardiovasc Thorac Surg 2002;1:99-101. CrossRef

5. Salim F, Ramesh V.Tension gastrothorax: a rare complication.J Coll Physicians Surg Pak 2009;19:325-6.

6. Akhtar MS, Beg MH, Kumar A. Isolated Traumatic Giant Diaphragmatic Hernia Mimicking a Haemopneumothorax: A Report of Two Cases. Chest Dis Allied Sci 2012;54:259-61.

\section{OLGU SUNUMU - ÖZET}

\section{Genç bir kadında, non-travmatik tansiyon gastrotoraks}

\section{Dr. Mahmut Tokur, ${ }^{1}$ Dr. Ş. Mustafa Demiröz, ${ }^{1}$ Dr. Muhammet Sayan ${ }^{2}$}

${ }^{1}$ Kahramanmaraş Sütçü Imam Üniversitesi Tıp Fakültesi, Göğüs Cerrahisi Anabilim Dalı, Kahramanmaraş ${ }^{2}$ Aksaray Devlet Hastanesi, Göğüs Cerrahisi Kliniği, Aksaray

Bir diyafragmatik defektten toraksa herniye olarak masif distansiyona uğrayan mide dokusunun neden olduğu tansiyon gastrotoraks oldukça nadir, ancak ölümcül olabilen bir klinik durumdur. Akciğer ve mediasten basısına bağlı ciddi semptomlara neden olur. Nefes darlığı şikayeti ile acil servise başvuran ve travma öyküsü olmayan 27 yaşında kadın hasta, ilk değerlendirme sonrası göğüs cerrahisi kliniğine konsülte edildi. Toraks bilgisayarlı tomografide sol hemitoraksda gastrotoraks tespit edildi. Hastanın arrest olması nedeniyle resüsitasyona başlandı ve acil sol torakotomi yapılarak abdominal organlar redükte edildi ve diyafragmatik defekt primer onarıldı. Hasta operasyon sonrası beşinci gün sorunsuz şekilde taburcu edildi.

Anahtar sözcükler: Diyafragma ruptürü; acil torakotomi; tansiyon gastrotoraks.

Ulus Travma Acil Cerrahi Derg 2015;2I (4):306-308 doi: 10.5505/tjtes.20I5.71245 